\title{
Tinjauan Yuridis Pajak Restoran Atas Food Truck
}

\author{
Achmad Paku Braja Arga A. \\ Pascasarjana Fakultas Hukum Universitas Indonesia
}

\begin{abstract}
Innovation in the restaurant business is very dynamic, this can be seen in the emergence of the Food Truck business. Food Truck is a new type of business selling food that uses vehicles as a place of sale, so it can move. The definition of restaurant in the restaurant tax regulation does not mention Food Truck, but there are similar concepts so that it has the potential to cause multiple interpretations relating to the understanding of the subject of restaurants and restaurant tax objects. This paper aims to analyze Food Truck from the perspective of tax law as well as specifically related to local taxes.
\end{abstract}

Keywords: Tax, Restaurant Taxes, Food Truck, Local Taxation.

Abstrak. Inovasi pada bidang usaha restoran sangat dinamis, hal ini nampak pada munculnya jenis usaha Food Truck. Food Truck merupakan jenis usaha baru dari usaha penjualan makanan yang menggunakan kendaraan sebagai tempat penjualan, sehingga dapat berpindah tempat. Definisi restoran dalam regulasi pajak restoran tidak menyebutkan Food Truck, akan tetapi terdapat konsep sejenisnya sehingga berpotensi menimbulkan multi interpretasi berkaitan dengan pengertian restoran subjek dan objek pajak restoran. Makalah ini ini bertujuan untuk menganalisis Food Truck dari sudut pandang hukum pajak serta secara spesifik terkait dengan pajak daerah.

Kata Kunci: Pajak, Pajak Restoran, Food Truck, Pajak Daerah

\section{PENDAHULUAN}

Pajak menurut sejarahnya bermula dengan wujud upeti yakni pemberian rakyat kepada raja atau penguasa yang bersifat kewajiban sehingga dipaksakan agar dilaksanakan. Pemberian rakyat itu berupa hasil pertanian yang digunakan untuk keperluan kerajaan atau penguasa tanpa adanya imbalan yang dapat dirasakan oleh rakyat sehingga murni untuk kepentingan sepihak. Seiring dengan perkembangan zaman, pemberian rakyat tersebut tidak saja hanya untuk kepentingan kerajaan akan tetap sudah berarah untuk kepentingan rakyat juga.

Pajak telah dipungut di Indonesia sejak awal kemerdekaan sebagai sumber penerimaan negara. Pungutan pajak bersifat memaksa dan terutang oleh wajib pajak dengan tidak mendapat prestasi secara langsung, serta hasil dari pungutan pajak digunakan untuk membiayai pengeluaran negara dalam penyelenggaraan pemerintahan

Jurnal Ilmu Sosial dan Pendidikan
Pungutan pajak adalah penghasilan negara yang berasal dari rakyat, sehingga dapat mengurangi kekayaan atau penghasilan individu. Akan tetapi sebaliknya dari berkurangnya kekayaan atau penghasilan kemudian dikembalikan lagi kepada masyarakat dengan melalui pengeluaran-pengeluaran negara dalam pembangunan yang pada akhirnya akan kembali lagi kepada masyarakat. Untuk itu pajak merupakan salah satu opsi atau pilihan yang tepat untuk optimalisasi pendapatan negara

Sejak tahun 2001 Indonesia secara formal telah menjalankan desentralisasi pemerintahan dengan semangat tunggal memberikan kewenangan yang lebih besar kepada daerah untuk mengurus dirinya sendiri, termasuk dalam hal ekonomi dan pelaksanaan pembangunan. Berdasarkan Undang-Undang Nomor 32 Tahun 2004 tentang Pemerintahan Daerah jo Nomor 12 Tahun 2008 dan UndangUndang Nomor 33 Tahun 2004 tentang 
Perimbangan Keuangan antara Pemerintah Pusat dan Pemerintahan Daerah, maka penyelenggaraan pemerintahan daerah dilakukan dengan memberikan kewenangan yang seluas-luasnya, disertai dengan pemberian hak dan kewajiban menyelenggarakan otonomi daerah dalam kesatuan sistem penyelenggaraan pemerintahan negara. Salah satunya kewenangan yang diberikan kepada pemerintah daerah untuk memungut pajak daerah dan retribusi daerah sesuai dengan tata cara dan substansi yang diatur dalam Undang-Undang yang selanjutnya digantikan dengan UndangUndang Nomor 23 Tahun 2014 tentang Pemerintahan Daerah.

Penyelenggaraan fungsi pemerintahan daerah dapat terlaksana dengan baik apabila diikuti dengan pembagian sumber-sumber penerimaan yang cukup kepada daerah yang mengacu pada Undang-Undang Nomor 1 Tahun 2004 tentang Keuangan Negara, dimana besaran keuangan antara pusat dan daerah disesuaikan dan diselaraskan dengan pembagian kewenangan antara pemerintah pusat dengan daerah. Semua sumber keuangan yang melekat dalam setiap urusan pemerintah diserahkan menjadi sumber keuangan daerah.

Desentralisasi fiscal atau pembiayaan otonomi daerah merupakan salah satu komponen utama pelaksanaan desentralisasi dalam otonomi daerah. Adanya otonomi daerah telah merubah paradigma penyelenggaraan pemerintahan yang ada didaerah, dimana kekuasaan yang dulu bersifat sentralistik menjadi desentralistik dengan memberikan kepada daerah otonomi yang luas. Perubahan kebijakan dalam pemerintahan daerah menjadi suatu dasar atau pijakan bagi pemerintah daerah dalam pemungutan pajak dan retribusi daerah untuk menggali potensi pendapatan daerah masing-masing khususnya pendapatan asli daerah, yakni Undang-undang Nomor 28 Tahun 2009 tentang Pajak Daerah dan Retribusi Daerah

Salah satu sumber penerimaan daerah berasal dari pajak restoran. Perkembangan usaha restoran menuntut pengusaha untuk mulai berinovasi dalam membuat usaha yang kreatif , sehubungan dengan hal tersebut muncul Food Truck sebaga tantangan zaman dan iklim usaha pada bidang resoran. Pengusaha menjalankan bisnis restoran dengan menggunakan model Food Truck yakni penjualan makanan yamg dapat berpindah dengan kendaraan, dalam peneilitian ini akan mengemukan analisis ,mengenai jenis usaha Food Truck dalam hal terkait dengan pajak daerah.

\section{Rumusan Masalah.}

Berdasarkan judul dan uraian latar belakang di atas, adapun yang akan dibahas di dalam makalah ini, yaitu :

1. Apakah Food Truck merupakan objek dan/atau subjek pajak daerah ?

2. Bagaimana Penerapan Hukum terhadap Foodtruck sebagai objek dan/atau subjek pajak daerah?

\section{Tujuan Penulisan.}

Adapun tujuan penulisan ini adalah sebagai berikut :

1. Agar Pembaca Mengetahui bahwa Food Truck sebagai objek dan/atau subjek pajak daerah.

2. Agar Pembaca Mengetahui Tentang Bagaimana Penerapan Hukum terhadap Foodtruck sebagai objek dan/atau subjek pajak daerah.

\section{Kerangka Teori.}

Para ahli dalam bidang perpajakan yang memberikan batasan atau definisi yang berbeda-beda mengenai pajak, namun demikian berbagai definisi tersebut mempunyai inti atau tujuan yang sama dan ada beberapa definisi yang diungkapkan oleh para pakar antara lain :

Leroy Beaulicu.

"Pajak adalah bantuan, baik secara langsung maupun tidak yang dipaksakan oleh kekuasaan publik dari penduduk atau dari barang, untuk menutup belanja pemerintah"

Deutsche Reichs Abgaben

Ordnung. Pajak adalah bantuan uang secara insidental atau secara periodik (dengan tidak ada kontraprestasinya), yang clipungut oleh 
badan yang hersifat umum (= negara), untuk memperoleh pendapatan, di mana terjadi suatu tatbestand (= sasaran pemajakan), yang karena unclang undang telah menimbulkan utang pajak.

Soeparman Soemahamidjaja

Pajak adalah iuran wajib, berupa uang atau barang, yang dipungut oleh penguasa berdasarkan norma-norma hukum, guna menutup biaya produksi barang-barang dan jasa-jasa kolektif dalam mencapai kesejahteraan umum.

Prof. Dr. Rochmat Soemitro.

Pajak adalah iuran rakyat kepada kas negara herdasarkan undang undang (yang dapat dipaksakan) dengan tidak mendapat jasa-jasa timbal (kontra-prestasi), yang langsung dapat ditunjukkan dan yang digunakan untuk membayar pengeluaran umum", dengan penjelasan sebagai berikut: "Dapat dipaksakan" artinya: bila utang pajak tidak dibayar, utang itu dapat ditagih dengan menggunakan kekerasan, seperti surat paksa dan sita, dan juga penyanderaan; terhadap pembayaran pajak, tidak dapat ditunjukkan jasa timbal- balik tertentu, seperti halnya dengan retribusi.

Menurut Undang-undang Nomor 34 Tahun 2004 Perubahan atas Undang-undang Nomor 18 Tahun 1997 tentang Pajak Daerah dan Retribusi Daerah, yang dimaksud dengan Pajak Daerah adalah :

Iuran wajib yang dilakukan oleh orang pribadi atau badan kepada daerah tanpa imbalan langsung yang seimbang, yang dapat dipaksakan berdasarkan peraturan perundang-undangan untuk membiayai penyelenggaraan pemerintahan daerah dan pembangunan daerah

Pajak Daerah Kabupaten dan Kota, oleh Undang-Undang Nomor 34 Tahun 2000 pasal 2 ayat (2) telah disebutkan jenisnya, terdiri dari pajak hotel, pajak restoran, pajak hiburan, pajak reklame, pajak penerangan jalan, pajak pengambilan bahan galian golongan c, dan pajak parkir. Dengan
Peraturan Daerah, kepada Daerah diberikan kewenangan untuk :

1. Menetapkan jenis pajak lain selain sebagaimana tersebut diatas, setelah memenuhi kriteria yang ditetapkan oleh pasal 2 ayat (4), yang secara lengkap dikutip sebagai berikut :

a. Bersifat pajak dan bukan Retribusi;

b. Obyek pajak terletak atau terdapat di wilayah Daerah Kabupaten/Kota yang bersangkutan dan mempunyai mobilitas yang cukup rendah serta hanya melayani masyarakat di wilayah Daerah Kabupaten/Kota yang bersangkutan;

c. Obyek dan dasar pengenaan pajak tidak bertentangan dengan kepentingan umum;

d. Obyek pajak bukan merupakan obyek pajak Provinsi dan/atau obyek pajak Pusat;

e. Potensinya memadai;

f. Tidak memberikan dampak ekonomi yang negatif;

g. Memperhatikan aspek keadilan dan kemampuan masyarakat; dan

h. Menjaga kelestarian lingkungan.

2. Menetapkan jenis dan tarif pajak daerah [pasal 3 ayat (3) bersambung dengan pasal 4 ayat (1).

Berdasarkan cara pemungutannya Pajak Daerah kabupaten/kota dibedakan menjadi 2 (dua) macam yaitu :

a. Pajak langsung adalah pajak-pajak yang bebannya harus dipikul sendiri oleh Wajib Pajak dan tidak dapat dilimpahkan kepada orang lain serta dikenakan secara berulangulang pada waktu-waktu tertentu, misalnya Pajak Penerangan Jalan, Pajak Parkir.

b. Pajak tidak langsung adalah pajak yang bebannya dapat dilimpahkan kepada orang lain dan hanya dikenakan pada hal-hal tertentu atau peristiwa-peristiwa tertentu saja, misalnya Pajak Hotel, Pajak Restoran, Pajak Hiburan, Pajak Reklame, Pajak Pengambilan dan Pengelolaan Bahan Galian Golongan C 
Perpajakan daerah harus memiliki ciri-ciri sebagai berikut :

a. Pajak daerah secara ekonomis dapat dipungut, berarti perbandingan antara penerimaan pajak harus lebih besar dari ongkos pemungutannya.

b. Relatif stabil, artinya penerimaan pajak tidak berfluktuasi terlalu besar, kadangkadang meningkat secara drastis dan ada kalanya menurun secara tajam.

c. Basis pajaknya harus merupakan perpaduan antara prinsip keuntungan (benefit) dan kemampuan untuk membayar (ability to pay).

Melihat definisi di atas dapat diambil kesimpulan bahhwa Pajak daerah merupakan pajak dalam konteks daerah yang dapat dipungut oleh Pemerintah Daerah dalam hal ini Pemerintah Provinsi, Pemerintah Kabupaten/Kota. Diatur berdasarkan Peraturan Daerah dan hasilnya untuk membiayai pembangunan daerah.

Dari segi kewenangan pemungutan pajak atas objek pajak daerah, pajak daerah dibagi menjadi 2 (dua) yakni :

1. Pajak Daerah yang dipungut oleh provinsi

2. Pajak Daerah yang dipungut oleh Kabupaten /kota

Perbedaan kewenangan pemungutan antara pajak yang dipungut oleh pemerintah provinsi dan pemerintah kabupaten/kota, yakni sebagai berikut

1. Pajak provinsi kewenangan pemungutan terdapat pada Pemerintah Daerah Provinsi, sedangkan untuk pajak kabupaten/kota kewenganan pemungutan terdapat pada Pemerintah Daerah kabupaten/kota.

2. Objek pajak kabupaten/kota lebih luas dib.andingkan dengan objek pajak provinsi, dan objek pajak kabupaten/kota masih dapat diperluas berdasarkan peraturan pemerintah sepanjang tidak bertentangan dengan ketentuan yang ada. Sedangkan pajak provinsi apabila ingin diperluas objeknya harus melalui perubahan dalam Undangundang.
Pajak daerah di Indonesia dapat di golongkan berdasarkan tingkatan Pemerintah Daerah, yaitu pajak daerah tingkat Provinsi dan pajak daerah tingkat Kabupaten/Kota. Penggolongan pajak seperti tersebut di atas diatur dalam Undang-undang No. 18 Tahun 1997 sebagaimana telah diubah dalam Undangundang Nomor 34 Tahun 2000 tentang Perubahan Undang-undang Republik Indonesia tentang Pajak Daerah dan Retribusi Daerah (Pasal 2 ayat 1 dan 2) serta Peraturan Pemerintah Nomor 65 Tahun 2001 tentang Pajak Daerah. Peraturan Pemerintah tersebut mengatur tentang obyek, subyek, dasar pengenaan pajak dan ketentuan tarif dari pajak daerah yang berlaku, baik sebelum maupun sesudah berlakunya Undang-undang Nomor 34 Tahun 2000.

Pajak dapat dikenakan dengan satu syarat mutlak yang harus dipenuhi adalah adanya objek pajak yang dimiliki atau dinikmati oleh wajib pajak. Pada dasarnya objek pajak merupakan manifestasi dari taatbestand (keadaan yang nyata). Dengan demikian, taatbestand adalah keadaan, peristiwa, atau perbuatan yang menurut peraturan perundang- undangan pajak dapat dikenakan pajak

Terminologi yang digunakan dalam Undang-undang No. 34 Tahun 2000 tentang Pajak daerah dan Retribusi daerah adalah sebagai berikut :

1. Subjek Pajak adalah orang pribadi atau badan yang dapat dikenakan pajak daerah. Dengan demikian, siapa saja baik orang pribadi atau badan yang memenuhi syarat objeknya ditentukan dalam suatu peraturan daerah tentang pajak daerah, akan menjadi subjek pajak.

2. Wajib Pajak adalah orang pribadi atau badan yang menurut peraturan perundangundangan perpajakan daerah diwajibkan untuk melakukan pembayaran pajak yang terutang, termasuk pemungut atau pemotong pajak tertentu. Oleh sebab itu, seseorang atau suatu badan menjadi wajib pajak apabila telah ditentukan oleh 
peraturan daerah untuk melakukan pembayaran pajak, serta orang atau badan yang diberi kewenangan untuk memungut pajak dari subjek pajak

Berdasarkan pengertian di atas menunjukkan bahwa wajib pajak dapat merupakan subjek pajak yang dikenakan kewajiban membayar pajak maupun pihak lain, yang bukan merupakan subjek pajak, yang berwenang untuk memungut pajak dari subjek pajak

\section{Kerangka Konseptual.}

\section{Metode Pendekatan.}

Metode pendekatan dalam penelitian ini menggunakan metode kualitatif dengan pendekatan yuridis normatif. Penelitian hukum normatif yang merupakan studi dokumen, menggunakan pendekatan perundangundangan. Dalam penelitian ini yang diteliti adalah sampai sejauh mana hukum positif tertulis yang ada itu sinkron atau serasi satu sama lain. Hal ini dapat dilakukan melalui 2 (dua) jalur, yaitu

a. Vertikal, melihat apakah suatu peraturan perundang-undangan berlaku bagi suatu bidang kehidupan tertentu tidak saling bertentangan antara satu dengan yang lain apabila dilihat dari sudut vertikal atau hierarki peraturan perundang-undangan yang ada.

b. Horisontal, apabila yang ditinjau adalah peraturan perundangundangan yang berkedudukan sederajat dan yang mengatur bidang yang sama

Kegiatan dalam penelitian hukum normatif meliputi :

a. Memilih pasal-pasal yang bersifat norma hukum.

b. Menyusun sistematika dari pasal-pasal tersebut sehingga menghasilkan klasifikasi tertentu.

c. Menganalisis pasal-pasal tersebut dengan menggunakan asasasas hukum yang ada.

d. Menyusun suatu konstruksi dengan persyaratan :

i. Mencakup semua bahan hukum yang diteliti.

ii. Konsisten. iii. Memenuhi syarat-syarat estetis.

iv. Sederhana.

\section{Sistematika Penulisan.}

Untuk memberikan gambaran yang jelas mengenai hasil penelitian, maka setelah dianalisis akan dibuat pemaparan yang sistematikanya tersusun dalam 4 (empat) bab sebagai berikut :

Bab I merupakan Pendahuluan yang menguraikan tentang latar belakang masalah, tujuan penelitian, manfaat penelitian, kerangka teori, kerangka konseptual dan sistematika penulisan.

Bab II merupakan Tinjauan Pustaka akan diuraikan melalui kerangka pemikiran tentang pengertian pajak, asas dan teori pemungutan pajak, teknik pemungutan pajak, pajak daerah, jenis pajak daerah, obyek, subyek, wajib pajak daerah, retribusi daerah, obyek retribusi daerah, Negara hukum dan otonomi daerah.

Bab III merupakan Hasil penelitian dan analisis, melalui data-data yang terkumpul selama penelitian baik data primer maupun sekunder kemudian 30 dianalisis melalui metode yang digunakan, maka dalam bab ini akan diuraikan dasar hukum sistem pemungutan pajak daerah dalam era otonomi daerah, sistem pemungutan pajak daerah dalam era otonomi daerah, konsistensi antara peraturan daerah yang mengatur pajak daerah dengan peraturan perundang-undangan di bidang pajak daerah.

Bab IV merupakan Penutup meliputi kesimpulan dari masing-masing fokus penelitian dan saran-saran yang bersifat konstruktif yang dapat digunakan sebagai acuan dalam pelaksanaan kebijakan. Dengan demikian penelitian ini diharapkan memberikan manfaat dalam pengembangan ilmu pengetahuan dan bagi daerah dalam melakukan pemungutan pajak daerah.

\section{PEMBAHASAN PERMASALAHAN 1}

Menurut UU Pajak daerah dan Retribusi Daerah pasal 1 ayat 10 menyatakan bahwa 
"Pajak Daerah adalah kontribusi wajib kepada Daerah yang terutang oleh orang pribadi atau badan yang bersifat memaksa berdasarkan Undang-Undang, dengan tidak mendapatkan imbalan secara langsung dan digunakan untuk keperluan Daerah bagi sebesar-besarnya kemakmuran rakyat". Pajak daerah yang mana dalam rangka pembiayaan desentralisasi mendukung pemberian kewenangan kepada daerah merupakan pajak daerah yang baik karena hasilnya digunakan untuk pembiayaan rumah tangga daerah itu sendiri. Sehingga dalam kaitannya dengan pelaksanaan otonomi daerah, maka pemberian kewenangan pemungutan pajak selain dalam mempertimbangkan kriteria-kriteria perpajakan yang berlaku secara umum juga harus mempertimbangkan ketepatan suatu jenis pajak sebagai pajak daerah.

Jenis Pajak menurut UU Pajak daerah dan Retribusi Daerah dalam pasal 2 ayat 1 menyatakan bahwa "Jenis Pajak provinsi terdiri atas Pajak Kendaraan Bermotor, Bea Balik Nama Kendaraan Bermotor, Pajak Bahan Bakar Kendaraan Bermotor, Pajak Air Permukaan dan Pajak Rokok". Selanjutnya dalam pasal 2 ayat 2 menyatakan "Jenis Pajak kabupaten/kota terdiri atas Pajak Hotel, Pajak Restoran, Pajak Hiburan, Pajak Reklame, Pajak Penerangan Jalan, Pajak Mineral Bukan Logam dan Batuan, Pajak Parkir, Pajak Air Tanah, Pajak Sarang Burung Walet, Pajak Bumi dan Bangunan Perdesaan dan Perkotaan, dan Bea Perolehan Hak atas Tanah dan Bangunan". Dalam hal ini jenis pajak kabupaten/kota mempunyai jenis pajak yang lebih banyak dibandingkan dengan jenis pajak provinsi.

Salah satu sektor pajak yang diharapkan memberikan kontribusi yang signifikan dalam penerimaan keuangan daerah adalah pajak restoran, disamping pajak-pajak lain seperti pajak hiburan, pajak hotel, pajak reklame, dan lain-lain. Dengan demikian, pertumbuhan ekonomi berkolerasi positif dengan tumbuh dan berkembangnya usaha di bidang Restoran. Pajak restoran merupakan pajak yang potensial, hal itu karena Pajak restoran memiliki kontribusi besar terhadap pajak daerah sehingga penerimaannya sangat penting untuk dilakukan upaya peningkatan ke depannya.

Berdasarkan UU Pajak Daerah dan Retribusi Daerah yang tercantum dalam pasal 1 ayat 23 menyatakan bahwa "Restoran adalah fasilitas penyedia makanan dan/atau minuman dengan dipungut bayaran, yang mencakup juga rumah makan, kafetaria, kantin, warung, bar, dan sejenisnya termasuk jasa boga/katering", akan tetapi yang dimaksud dengan sejenisnya ini tidak dijelaskan secara rinci sehingga dapat multi tafsir dalam menjabarkan pengertian restoran. Kalau kita kaji secara rinci yang dimaksud dengan Restoran adalah suatu usaha yang menggunakan suatu bangunan dimana setiap orang dapat menyantap makanan dan minuman serta memperoleh pelayanan serta menggunakan fasilitas lainnya dengan pembayaran.

Trend baru telah lahir di Indonesia yakni Food Truck sebagai media untuk melakukan usaha. Menurut kamus Oxford bahwa Food Truck adalah kendaraan besar yang digunakan untuk memasak dan menjual makanan serta dilengkapi perabotan dan peralatan. Food Truck ini merupakan jenis rumah makan modern yang sering kita jumpai pada jaman sekarang terutama pada daerah perkotaan yang sifatnya berpindah tempat dalam memperdagangkan dagangannya akan tetapi apa yang disediakan dapat berupa makanan atau minuman. Perbedaan konsep antara restoran dengan Food Truck bahwa dalam Restoran mempunyai sifat adanya sebuah bangunan yang menetap akan tetapi Food Truck ini bersifat berpindah tempat. Perlu adanya kajian terhadap subjek pajak,wajib pajak, dan objek pajak restoran itu sendiri.

Subjek pajak dan wajib pajak dalam pajak restoran memiliki pengertian yang berbeda. Menurut pasal 38 UU Pajak Daerah dan Retribusi Daerah bahwa "Subjek Pajak Restoran adalah orang pribadi atau Badan yang membeli makanan dan/atau minuman dari Restoran" sedangkan "Wajib Pajak Restoran adalah orang pribadi atau Badan yang 
mengusahakan Restoran". Hal ini berarti subjek pajak restoran yakni pihak yang melakukan pembayaran pajak restoran atas pembelian makanan dan/atau minuman. Tidak sama dengan wajib pajak restoran yakni pengusaha restoran yang diberikan kewenangan untuk memungut pajak restoran dari subjek pajak. Food Truck dalam hal subjek pajak dan wajib pajak memiliki kesamaan dengan restoran.

Selanjutnya kajian UU Pajak Daerah dan Retribusi Daerah dalam hal pajak restoran mengenai obyek pajak restoran ada pada pasal 37 yang menyatakan bahwa suatu pelayanan yang disediakan oleh Restoran. Pelayanan yang disediakan Restoran mencakup pelayanan penjualan makanan dan/atau minuman yang dikonsumsi baik di tempat pelayanan maupun di tempat lain oleh pembeli.

bahwa:

Menurut Black"s Law Dictionary

"Service is labour performed in the interest or under direction of others specif., the performance of some useful act or series of acts for the benefit of another, use, for a fee". 29

Terjemahan bebasnya bahwa Pelayanan merupakan suatu tindakan yang dilakukan dibawah arahan orang lain yang mempunyai arti luas, sehingga pelayanan yang diberikan yang diberikan oleh restoran dapat diartikan sama dengan pelayanan yang diberikan Food Truck. Kesamaan dalam pelayanan yang diberikan berarti juga kesamaan dalam objeknya.

Walaupun ada yang tidak termasuk objek Pajak Restoran yakni pelayanan yang disediakan oleh Restoran yang nilai penjualannya tidak melebihi batas tertentu yang ditetapkan dengan Peraturan Daerah. Menurut Peraturan Daerah Kabupaten Lamongan Nomor 12 Tahun 2010 tentang Pajak Daerah dalam pasal 16 menyatakan bahwa pelayanan yang disediakan oleh restoran merupakan objek pajak restoran, akan tetapi pelayanan yang nilai penjualannya tidak melebihi dari $\mathrm{Rp}$. $500.000,00$ (lima ratus ribu rupiah) per hari tidak termasuk obyek Pajak Restoran. Alat ukur yang tidak termasuk objek pajak restoran atas
Food Truck yakni dari besaran nilai penjualannya tidak melebihi batas sesuai peraturan daerah dimana Food Truck itu melakukan usaha.

Dengan demikian, dari segi obyek dan subyek pajak restoran yang di jelaskan di atas, Food Truck dapat dimasukkan dalam kriteria "sejenisnya" yang di jelaskan pada UU Pajak Daerah dan Retribusi Daerah. Selain itu dapat ditafsirkan bahwa Food Truck memiliki subyek pajak, wajib pajak, dan objek pajak yang sama dengan pajak restoran yang dijelaskan dalam UU Pajak Daerah dan Retribusi Daerah.

\section{PEMBAHASAN PERMASALAHAN 2}

Objek pajak restoran adalah pelayanan yang disediakan oleh rumah makan, restoran, dan semacamnya. Biasanya, pelayanan yang disediakan meliputi pelayanan penjualan makanan/minuman yang dibeli atau dikonsumsi oleh pembeli. Baik dikonsumsi di tempat maupun dibawa pulang atau dimakan di tempat lain.

Selain itu, ada juga yang tidak termasuk dalam objek pajak, yakni pelayanan yang disediakan restoran yang pengelolaannya tergabung atau menjadi satu manajemennya dengan sebuah hotel. Selain itu, pelayanan yang disediakan oleh suatu restoran yang nilai penjualannya tidak melebihi $\mathrm{Rp}$ 200.000.000/tahun. Sedangkan subjek pajak restoran adalah orang pribadi maupun badan yang membeli makanan atau minuman dari suatu restoran atau tempat makan yang dikunjungi.

Cara menghitung pajak restoran berdasarkan pada pokok pajak restoran yang terutang, yakni dengan mengalikan tarif pajak $10 \%$ dengan dasar pengenaan pajak. Dasar pengenaan pajak merupakan sejumlah bayaran yang diterima atau yang seharusnya dipungut oleh restoran.

Contohnya:

Pajak Restoran: Dasar pengenaan paja $\mathrm{x}$ Tarif pajak

Dasar pengenaan pajak (nominal pembayaran yang diterima/dipungut sesuai 
dengan struk atau dokumen lainnya yang sejenis) $=$ Rp60.000.000

Tarif pajak $=10 \%$

Maka, pajak restorannya = Rp60.000.000 x 10\% = Rp6.000.000

Walaupun belum ada pembidangan jenis usaha dan legalisasi, bukan berarti usaha makanan ini bisa bebas dari pajak.

Implementasi pajak didasarkan atas PP

No. 46 Tahun 2013 tentang PPh atas Penghasilan dari Usaha yang Diterima atau Diperoleh Wajib Pajak dengan pengenaan pajak $1 \%$ pada tiap Peredaran Bruto Tertentu, analis tentang pembayaran pajak $1 \%$ terletak pada setiap Pendapatan Bruto yang diterima bila menujukkan angka 48 Milyar pada tiap pendapatan per tahun.

Hanya saja aturan ini tidak berlaku bagi pedagang-pedagang asongan, pedagang kaki lima atau pedagang yang tidak memiliki tempat yang tetap. Dalam PP jelas disebutkan, pengecualian terhadap Wajib Pajak yang melakukan kegiatan usaha perdagangan dan atau jasa yang dalam menggunakan sarana atau prasarana yang dapat dibongkar pasang dan menggunakan sebagian atau seluruh tempat untuk kepentingan umum yang tidak diperuntukkan bagi tempat usaha tau berjualan. Misalnya pedagang makan keliling, pedagang asongan dan warung tenda di trotoar.

Menurut ketentuan dari PP tersebut, jelas analisis bahwa food truck tidak masuk dalam kriteria wajib pajak.

Hanya saja ketika jenis usaha ini dibidangkan dalam bisnis waralaba tentu akan berbeda analisisnya. Secara hukum, menurut Peraturan Menteri Perdagangan Nomor 31 Tahun 2008 Tentang Waralaba, ada beberapa kriteria yang harus dipenuhi antara lain sebagai berikut :

a. Memiliki ciri khas usaha

b. Terbukti sudah memeberikan keuntungan

c. Memiliki standar atas pelayanan dan barang atau jasa yang ditawarkan yang dibuat secara tertulis

d. Mudah diajarkan dan diaplikasikan e. Adanya dukungan yang berkesinambungan dan

f. Adanya Hak Kekayaan Intelektual (HKI) yang telah terdaftar.

Aspek pajak yang diwajibkan bagi usaha waralaba ini diantaranya adalah PPN, Pajak Penghasilan ( $\mathrm{PPh}$ ) perorangan dan Pajak Penghasilan Badan dan Bentuk Usaha Tetap.

Tarif service charge biasanya tidak melebihi Pajak Restoran. Jadi, rata-rata pengenaan service charge sebesar 5\%. Hal yang sama juga diterapkan pada pajak perhotelan. Akan tetapi, biasanya service charge hotel lebih tinggi dari restoran, yakni $10 \%$. Hal ini tergantung kebijakan dari tempat makan atau restoran yang terkait.

Pada dasarnya, biaya pelayanan atau service charge merupakan salah satu dasar dari pengenaan Pajak Daerah. Hal tersebut tercantum dalam Peraturan Gubernur Provinsi DKI Jakarta No. 92 Tahun 2011 tentang pelaksanaan Online System Atas Pelaporan Data Transaksi Usaha Wajib Pajak Hotel, Pajak Restoran, Pajak Hiburan, dan Pajak Parkir.

Pengenaan service charge disesuaikan dengan kebijakan pihak restoran, apakah ingin dikenakan atau tidak. Oleh karena itu, Anda mungkin sering kali melihat ada beberapa restoran yang memungut service charge dan ada juga yang tidak.

Bila pelayanan di suatu restoran dikenakan service charge, maka tagihan service charge biasanya akan ditambahkan terlebih dahulu pada tagihan belanjaan Anda, sebelum dikenakan pajak restoran.

\section{KESIMPULAN}

1. Food Truck merupakan model usaha baru dalam bisnis makanan dan/atau minuman dengan menggunakan mobil untuk melakukan usahanya. Dalam hal usaha yang baru ini, UU Pajak Daerah dan Retribusi Daerah tidak memberikan dasar pengenaan pajak restoran terhadap Food Truck. Konsep dalam pengertian Restoran juga berbeda, karena Food Truck dalam menjalankan usahanya menggunakan mobil 
sehingga dapat berpindah-pindah. Dalam kajian Food Truck dapat dimasukkan dalam kriteria "sejenisnya" yang di jelaskan pada UU Pajak Daerah dan Retribusi Daerah. Selain itu dapat ditafsirkan bahwa Food Truck memiliki subyek pajak, wajib pajak, dan objek pajak yang sama dengan pajak restoran dijelaskan dalam UU Pajak Daerah dan Retribusi Daerah.

2. Pengenaan pajak Terhadap Food Truck memang belum diatur secara nasional, mengingat bahwa jenis usaha Food Truck tidak selalu ada pada tiap daerah dan mungkin belum dipandang sebagai sebuah potensi pendapatan daerah. Namun hal tersebut berbeda jika pada suatu daerah terdapat banyak jenis usaha Food Truck maka pengaturan pengenaan pajak akan dituangkan dalam suatu produk hukum misalnya yang terjadi Provinsi DKI Jakarta.

\section{SARAN}

1. Perlu adanya persamaan pemahaman mengenai pendefinisian jenis usaha Food Truck sebagai objek dan/atau subjek pajak, sehingga terdapat pemetaan yang jelas berkaitan dengan potensi pendapatan daerah dari jenis usaha Food Truck dapat dikategorikan sebagai objek dan/atau seubjek pajak.

2. Perlu adanya penyamaan visi mengenai pengenaan pajak terhadap Food Truck sehingga dapat memaksimalkan potensi pendapatan daerah yang memiliki jenisusaha Food Truck, serta hal tersebut dapat memberikan kejelasan kepada pengusaha untuk dapat mengkalkulasikan kewajiban pembayaran pajak dalam biaya operasionalnya.

\section{DAFTAR PUSTAKA}

Adegustara, Frenadin, Syofiarti, dan Titin Fatimah, "Kontribusi Pajak Daerah Dan Retribusi Daerah Terhadap Peningkatan Pendapatan Asli Daerah Dalam Rangka Pelaksanaan Otonomi Daerah (Studi di Tiga Daerah Di
Propinsi Sumatera Barat)", Jurnal Ilmu Hukum, Vol. 2 No. 2, Universitas Riau, 2009.

Brotodihardjo, R. Santoso, SH. Pengantar Ilmu Hukum Pajak, PT. Refika Aditama, Bandung. Cet Pertama Edisi Keempat, 2003.

Dotulong, Garry A.G. David P.E. Saerang, dan Agus T Poputra,," "Analisis Potensi Penerimaan Dan Efektivitas Pajak Restoran Di Kabupaten Minahasa Utara", Jurnal Berkala Ilmiah Efisiensi, Vol. 14 No. 2, Universitas Sam Ratulangi Manado, 2014.

Humanis, UNISDA Press, Vol. 3 No. 1, 2011.

Ilyas, Wirawan B. dan Richard Burton, Hukum Pajak (Teori, Analisis, dan Perkembangannya), Salemba Empat, Jakarta, 2014.

Ismail, Tjip, Pengaturan Pajak Daerah di Indonesia, Yellow Printing, Jakarta, 2007.

Lembaran Negara Republik Indonesia Tahun 2003 Nomor 47, Tambahan Lembaran Negara Republik Indonesia Nomor 4286, untuk selanjutnya disingkat UUKN

Lembaran Negara Tahun 2009 Nomor 180, Tambahan Lembaran Negara Tahun Nomor 5049, Selanjutnya disingkat UU Pajak Daerah dan Retribusi Daerah

Lembaran Negara Tahun 2014 Nomor 244, Tambahan Lembaran Negara Tahun Nomor 5587, Selanjutnya disingkat UU Pemerintahan Daerah.

Munir, Ahmad, "Pembebasan Pajak pertambahan nilai atas Usaha Mikro Kecil dan Menengah",

Putranti, Mawar Dwi, Pengaruh Penerimaan Pajak Reklame dan Pajak Restoran Terhadap Pendapatan Asli Daerah, Universitas Islam Negeri Syarif Hidayatullah, Jakarta, 2008.

Siahaan, Marihot P., Pajak Daerah dan Retribusi Daerah, Raja Grafindo, Jakarta, 2005. Sunggono, Bambang, 
Jurnal Ilmu Sosial dan Pendidikan

http://ejournal.mandalanursa.org/index.php/JISIP/index

Terakreditasi Peringkat 5 (No. SK: 85/M/KPT/2020)

Metodologi Penelitian Hukum, Raja

Grafindo Persada, Jakarta, 2007.
Vol. 5. No. 1 Januari 2021

p-ISSN: 2598-9944 e- ISSN : 2656-6753 